\title{
EMOTIONAL MATURITY AND PERSONALITY DEVELOPMENT OF SENIOR SECONDARY SCHOOL STUDENTS
}

\author{
Anumeha $^{1}$, Dr. (Fr.) Ignatius Topno S.J. ${ }^{2}$ \\ ${ }^{1}$ Research Scholar, School of Educational Training and Research, Aryabhatta Knowledge University, Patna, Bihar. \\ ${ }^{2}$ Department of Education, St. Xavier's College of Education (Autonomous), Patna
}

\begin{abstract}
The present study examines the emotional maturity and personality development of senior secondary school students. The sample comprises of 200 students (100 male and 100 female) from Patna district of Bihar. Self -constructed and validated tool on emotional maturity and personality development was used for the study. The data was analysed using ' $\mathrm{t}$ ' test. The results indicated that there is significant difference between male and female senior secondary school students in emotional maturity. There is no significant difference between urban and rural senior secondary school students in the level of emotional maturity. There is no significant difference between male and female senior secondary school students in the level of personality development but there is significant difference between urban and rural senior secondary school students in the level of personality development.
\end{abstract}

Keywords: Emotional Maturity, Personality Development, Senior Secondary School Students

\section{INTRODUCTION}

Adolescents are the pillars of a nation. The senior secondary school phase belongs to the peak of adolescence era. They not only represent a massive institution however they are also the unique agencies of our society. As the adolescence phase is called the transition phase, the youngsters need to balance themselves during this phase. They are required to inculcate positive behavioural requirement that would help in the betterment of the society. The senior secondary school students undergo a lot of challenges like opting careers, college selection, stream selection, making a place in the family, getting identified in the society, adapting a suitable lifestyle. The length of this period is of notable significance as the adolescents undergo a lot of mood swings which might drive them towards anti- social behaviour like drug addiction, cybercrimes, taking shortcuts for a bright career etc. it can be said that this phase is like the two sides of the same coin. Stress, depression and confusion on one side and positive personality development on the other side. Since the adolescents experience various mental and physical changes, they need full and proper care and guidance during this complex phase of live for enhancing their positive personality development, in understanding and controlling their emotions, understanding their skills and capabilities in decision making. Although it is a period of storm and strife but an adolescent need to groom himself to stand and make a place in the society. During this period the maximum development of an individual's personality takes place. The attitude which a teenager holds towards himself dealing with emotional maturity and self- worth play an important role in the development of personality. People having high emotional maturity face the difficulties in life firmly and work in a positive manner showing a positive personality development.

Emotional maturity: in the prevailing scenario every individual is facing difficulties in life. These hardships are resulting in a number of psycho somatic problems such as anxiety, tension, stress, depression frustrations and emotional ups and downs in daily life. Emotional maturity now a days emerging as a descriptive science. It helps in understanding that emotions play an important role in the life of an individual. It is expected from an individual to have high emotional maturity in order to lead a stress free life.

Personality development: The personality pattern is a unified multidimensional structure in which the concept of self is the core or centre of gravity. (Breckenridge and Vincent, 1965). Personality encompasses the entire nature of the individual and is therefore difficult to define. It is the result of lifelong experiences and influences. Each of us has a quality of behaviour. This general quality of self-behaviour is what we understand by personality. Personality is the dynamic organization within the individual of these psychological systems that determine their unique adaptation to the environment. A person's personality determines how he reacts to other people and how other people react to him. In short, personality is what makes possible a prediction of what a person will do in a given situation. Development is a chain of habitual tendencies. Development of personality takes place under the influence of society and environment. 
International Advanced Research Journal in Science, Engineering and Technology

\author{
Vol. 8, Issue 12, December 2021 \\ DOI: 10.17148/IARJSET.2021.81204 \\ 2. REVIEW OF RELATED LITERATURE
}

Rawat and Singh (2017) studied on effect of family type on emotional maturity of adolescents. Findings of the study revealed that adolescents from joint families were more emotionally progressive, socially well adjusted, had adequate personality and were independent than those from nuclear families. The prominent reason for a significant difference in emotional maturity across family setup was observed to be family composition, climate and traditions, and confounding factors.

Kumar and Mishra (2016) reviewed studies on Emotional Maturity and Academic Achievement among Adolescent Students. The findings of the investigation revealed that there was a positive correlation between emotional maturity and academic achievement among Adolescence students. Thus, emotional maturity played an important role in the academic achievement of students.

Rawat and Singh (2016) conducted a study on emotional maturity of adolescents with respect to their educational settings . Results revealed that adolescents from coeducational schools, in both the districts, were more emotionally progressive, socially adjusted and independent as compared to those studying in non-coeducational schools. The prominent reason for significant difference in emotional maturity across different educational setting was observed to be school gender composition, school climate and traditions, and confounding factors.

Pranab, Jadab and Soni (2015) found that there existed a highly statistically significant relationship about self-concept among adolescents with respect to their delinquency proneness. The findings of the study revealed that self-concept of female adolescents who had proneness to delinquency was comparatively higher than male. The level of self-concept was found better among male non delinquency prone adolescents in comparison to female. The delinquency prone adolescents possessed a lower level of emotional maturity than non-delinquency prone counterpart. The emotional maturity of delinquency prone female adolescents was comparatively lower than male counterpart. The level of emotional maturity is found better among female non-delinquency prone adolescents in comparison to male. The male delinquency prone adolescents had a lower level of emotional maturity than the male adolescents with non delinquency proneness. The female adolescents with non-delinquency proneness possessed a better level of emotional maturity than delinquency proneness counterpart.

Dutta., Chetia \& Soni (2015) conducted a study on a comparative study on emotional maturity of Secondary School Students in Lakhimpur and Sonitpur Districts of Assam. The finding of the study reported that there were major differences in the emotional maturity of secondary school students of both districts whether they belong to rural and urban male /female, government and private male/female, rural male/female and private rural male/ female secondary schools students. This study also showed that there was no difference between urban male/female, private male/female and private urban male and female secondary students of both the districts on emotional maturity.

Kumar and Bakshi (2016) conducted a study on Personality traits and academic achievement of tribal (GADDI) secondary school students. This study was conducted to identify the 16 personality traits among tribal (Gaddi) secondary school students and to find out the gender difference in all the 16 personality traits and differences in the academic achievement of male and female Tribal (Gaddi) secondary school students. The results indicated that male and female tribal (Gaddi) secondary school students were also found to be average students in their 16 personality traits. It is also found that male and female Gaddi secondary school students did not differ significantly in their academic achievement. Omoruyi (2014) investigated on influence of broken homes on academic performance and

personality development of the adolescents in lagos state metropolis. This study investigated the influence of broken homes on academic performance and personality development of the adolescents in lagos state metropolis with particular focus on the Kosofe Local Government Area of Lagos State. The results revealed that there is a significant difference between single- parenting and academic performance of the adolescents, there is a significant difference between parental socio- economic status and academic performance, there is significant relationship between adolescents from broken homes and academic performance.

Akomolafe (2013) investigated on Personality Characteristics as Predictors of Academic Performance of Secondary School Students. The purpose of this study was to investigate the relationship of personality characteristics to academic performance of secondary school students. The correlational type of descriptive research design was used for the study. Findings showed that personality dimensions jointly and relatively predicted academic performance except neuroticism. The findings imply that teachers should construct learning environments that take into consideration students' individual differences and strengths. Appropriate counselling interventions should be used to assist students experiencing worry, anxiety, frustration and stress to deal with their concerns.

Perveen (2011) studied on personality dynamics of boarders and day scholars who belong to madrassah and public school The major objective of the present study was to assess and compare the personality dynamics of boarders and day scholars who belongs to Madrassah and Public schools. Population of the present included all female and male students studying in Public school and Madrassah in Hazara division. Gender wise analysis indicated that Madrassah female students exhibited high vulnerability for Anxiety and Depression than Public school students, while male students from Public 


\section{International Advanced Research Journal in Science, Engineering and Technology}

Vol. 8, Issue 12, December 2021

DOI: 10.17148/IARJSET.2021.81204

schools exhibited inclination towards Neuroticism and Extraversion as compares to Madrassah students. On the other hand both type of students manifested same level of Conscientiousness, Agreeableness, and Openness.

Mehmood (2011) studied on Impact of Co-curricular Activities on Personality Development of Secondary School Students. The study was designed to find out the impact of co-curricular activities on personality development of Secondary School Students. The objectives of the study were to find out the impact of co-curricular activities on developing confidence, honesty, sociability, sympathetic attitude, sense of responsibility, social obligation and adaptation among secondary school students. On the basis of data analysis, it was found that cocurricular activities have significant impact on selected personality traits.

\section{OBJECTIVES}

I.To study and compare the emotional maturity of male and female senior secondary school students.

II.To study and compare the personality development of male and female senior secondary school students.

III.To study and compare the emotional maturity of urban and rural senior secondary school students.

IV.To study and compare the personality development of urban and rural senior secondary school students.

\section{NULL HYPOTHESES}

i.There is no significant difference between mean scores of emotional maturity of male and female senior secondary school students.

ii.There is no significant difference between mean scores of personality development of male and female senior secondary school students.

iii.There is no significant difference between mean scores of emotional maturity of urban and rural senior secondary school students.

iv.There is no significant difference between mean scores of the personality development of urban and rural senior secondary school students.

\section{DELIMITATIONS}

i.The geographical area of the study is delimited to senior secondary schools of Patna.

ii.Sample has been selected on incidental purposive basis.

iii.Sample of the study is delimited to students of class 12 .

\section{SAMPLE}

200 senior secondary school students were selected by incidental purposive sampling method.

\section{TOOLS}

Following tools were used for collecting data for the study:

i.Self - constructed and validated tool on emotional maturity of senior secondary school students.

ii.Self- constructed and validated tool on personality development of senior secondary school students.

\section{DATA COLLECTION}

The data was collected by administering the tests in groups in two sessions. After data collection, scoring was done on the basis of Linkert scale. Statistical processes were applied to the data and results were obtained.

The researcher used mean, standard deviation and ' $t$ ' test.

\section{STATISTICAL TECHNIQUES}

\section{RESULT AND DISCUSSION}

The data collected through above mentioned questionnaire were analysed in terms of mean, standard deviation and t- test method. The results have been given in the table. 


\section{Null Hypothesis 1}

There is no significant difference between mean scores of emotional maturity of male and female senior secondary school students.

Table 1. Emotional Maturity of male and female senior secondary school students.

\begin{tabular}{|l|l|l|l|l|l|l|}
\hline VARIABLE & GROUP & N & MEAN & S.D. & t- value & REMARKS \\
\hline $\begin{array}{l}\text { Emotional } \\
\text { Maturity }\end{array}$ & Male & 100 & 61.59 & 7.075 & 6.021 & \multirow{2}{*}{ Significant } \\
\cline { 2 - 5 } & Female & 100 & 64.55 & 7.93 & & \\
\hline
\end{tabular}

(at 0.05 level of significance)

It is found that the mean scores of both male and female senior secondary school students are 61.59 and 64.55 respectively. When the t-test was applied to test the significance of the mean difference between these groups, it reported a t-value 6.021. This was found to be significant at 0.05 level of significance. Hence hypothesis 1 is rejected. This means that there is a significant difference in the mean scores of male and female senior secondary school students in their level of emotional maturity.

\section{Null Hypothesis 2}

There is no significant difference between mean scores of personality development of male and female senior secondary school students.

Table 2. Personality Development of male and female senior secondary school students.

\begin{tabular}{|l|l|l|l|l|l|l|}
\hline VARIABLE & GROUP & N & MEAN & S.D. & t- value & REMARKS \\
\hline \multirow{2}{*}{$\begin{array}{l}\text { Personality } \\
\text { Development }\end{array}$} & Male & 100 & 68.34 & 20.54 & 0.258 & \multirow{2}{*}{ Not Significant } \\
\cline { 2 - 5 } & Female & 100 & 71.4 & 15.60 & & \\
\hline
\end{tabular}

(at 0.05 level of significance)

It is found that the mean scores of both male and female senior secondary school students are 68.34 and 71.4 respectively. When the t-test was applied to compare the mean scores of both the groups, it was found that the calculated t-value is 0.258 which is not significant at 0.05 level of significance. Hence hypothesis 2 is accepted. This means that there is no significant difference in mean scores of male and female senior secondary school students in their level of personality difference.

\section{Null Hypothesis 3}

There is no significant difference between mean scores of emotional maturity of urban and rural senior secondary school students.

Table 3. Emotional Maturity of urban and rural senior secondary school students.

\begin{tabular}{|l|l|l|l|l|l|l|}
\hline VARIABLE & GROUP & N & MEAN & S.D. & t- value & REMARKS \\
\hline \multirow{2}{*}{$\begin{array}{l}\text { Emotional } \\
\text { Maturity }\end{array}$} & Urban & 100 & 64.21 & 11.94 & 1.798 & \multirow{2}{*}{ Not Significant } \\
\cline { 2 - 5 } & Rural & 100 & 73.15 & 12.85 & & \\
\hline
\end{tabular}

(at 0.05 level of significance)

It is found that the mean scores of urban and rural senior secondary school students are 64.21 and 73.15 respectively. When t-test was applied was to compare the mean scores of both the groups, it was found that the calculated t-value is 1.798 which is not significant at 0.05 level of significance. Hence hypothesis 4 is accepted. This means there is no difference between mean scores of urban and rural senior secondary school students in their level of emotional maturity.

\section{Null Hypothesis 4}

There is no significant difference between mean scores of the personality development of urban and rural senior secondary school students

Table 4. Personality Development of urban and rural senior secondary school students.

\begin{tabular}{|l|l|l|l|l|l|l|}
\hline VARIABLE & GROUP & N & MEAN & S.D. & t- value & REMARKS \\
\hline $\begin{array}{l}\text { Personality } \\
\text { Development }\end{array}$ & Urban & 100 & 110 & 35.58 & 2.869 & Significant \\
\cline { 2 - 6 } & Rural & 100 & 96 & 33.30 & & \\
\hline
\end{tabular}

(at 0.05 level of significance)

It is found that the mean scores of urban and rural senior secondary school students are 110 and 96 respectively. When t-test was applied to compare the mean scores of both the groups, it was found that the calculated t-value is 2.869 which is significant at 0.05 level of significance. Hence hypothesis 4 is rejected. This means that there is a significant difference in the mean scores of urban and rural senior secondary school students in their level of personality development. 


\section{FINDINGS OF THE STUDY}

i.There is a significant difference between mean scores of emotional maturity of male and female senior secondary school students.

ii.There is no significant difference between mean scores of personality development of male and female senior secondary school students.

iii. There is no significant difference between mean scores of emotional maturity of urban and rural senior secondary school students.

iv.There is a significant difference between mean scores of the personality development of urban and rural senior secondary school students.

\section{CONCLUSION}

The findings of the study show that male and female senior secondary school students differ in the level of emotional maturity. On the basis of emotional maturity, it can be concluded that female senior secondary school students mature faster than male senior secondary school students. This may be due to the tendency of female brain to establish connectivity faster than male brain via the process of preferential detachment. However, there is no difference in the level of emotional maturity of urban and rural senior secondary school students. The investigation of personality development shows that there is no significant difference in the mean scores of male and female senior secondary school students but the level of personality development in urban senior secondary school students is higher than rural senior secondary school students. It may be possible as the urban students have more exposure to social media, internet facilities and educational facilities than rural senior secondary school students.

\section{EDUCATIONAL IMPLICATIONS}

The study can be useful for parents, teachers, educators and planners while framing the education of senior secondary school students in the following ways:

i.The findings of the study may help parents and teachers in assessing the personality development of senior secondary school students and can provide conductive environment.

ii.It will help the teachers in developing positive attitude in the students which would help them in controlling their emotions and developing their personality.

iii.It will aid the teachers in making the young generation realize that they should be emotionally stable and self-confident to excel in their academic performance and enhance life skills to face the problem in future.

\section{REFERENCES}

1. Rawat, C.\& Singh, R. (2016). A study of emotional maturity of adolescents with respect to their educational settings. Retreived from https://www.researchgate.net/publication/313860803

2. Kunwr, A. \& Kumar, A.(2014). Impact of different factors on Emotional Maturity of adolescents of CoedSchool. International Research Journal of Social Sciences ISSN 2319-3565 Vol. 3(11), Retreived from http://www.isca.in/IJSS/Archive/v3/i11/3.ISCA-IRJSS-2014-178.pdf

3. Dutta Chetia \& Soni (2015) International Journal of Science and Research (IJSR) ISSN (Online): 2319-7064 Index Copernicus Value (2013): 6.14 | Impact Factor (2013): 4.438 Volume 4 Issue 9, September 2015 www.ijsr.net Licensed Under Creative Commons Attribution CC

4. Kumar \& Bakshi (2016) International Research Journal of Social SciencesISSN 2319-3565 Vol. 3(3), 6-8, March (2014) Int. Res. J. Social Sci. International Science Congress Association

5. Akomolafe (2013) ISSN 2039-2117 (online) ISSN 2039-9340 (print) Mediterranean Journal of Social Sciences Published by MCSER-CEMASSapienza University of Rome Vol 4 No 2 May 2013657 http://www.mcser.org/journal/index.php/mjss/article/viewFile/253/238

6. Perveen,S (2011) Department of Psychology Hazara University Mansehra PAKISTAN nav11649@yahoo.com Academic Research International ISSN: 2223-9553 Volume 1, Issue 1, July 2011 http://www.savap.org.pk/journals/ARInt./Vol.1(1)/2011(1.1-15).pdf

7. Mehmood, T. (2012). Impact of Co-Curricular Activities on Personality Development of Secondary School Students. Retreived from https://www.researchgate.net/publication/256022120

8. Omoruyi (2014) European Journal of Educational and Development Psychology Vol.2,No.2, pp.10-23, September 2014 Published by European Centre for Research Training and Development UK (www.eajournals.org) 10

9. Vyas T, \& Gunthey R (2017). Emotional Maturity and Self Confidence among Adolescent Students. International Journal of Indian Psychology, Vol. 5, (1), DIP: 18.01.069/20170501, DOI: 10.25215/0501.069 